\title{
Retraction Note: Endocrine disruptors induce perturbations in endoplasmic reticulum and mitochondria of human pluripotent stem cell derivatives
}

\author{
Uthra Rajamani, ${ }^{1,2}$, Andrew R. Gross ${ }^{1}$, Camille Ocampo ${ }^{1,3}$, Allen M. Andres ${ }^{4,5}$, Roberta A. Gottlieb (1) ${ }^{4,5} \&$ \\ Dhruv Sareen (1D 1,2,3,6
}

Retraction of: Nature Communications; https://doi.org/10.1038/s41467-017-00254-8; published online 09 August 2017

We the authors are retracting this Article as it has come to our attention that during figure assembly certain images were inappropriately processed in Figs. 3d, $4 \mathrm{~b}$ and $6 \mathrm{a}$ of the Article. These data integrity issues undermine our full confidence in the integrity of the study and the authors therefore wish to retract the Article.

All the authors agree with the retraction.

Published online: 02 February 2019

\begin{abstract}
(c) (i) Open Access This article is licensed under a Creative Commons Attribution 4.0 International License, which permits use, sharing, adaptation, distribution and reproduction in any medium or format, as long as you give appropriate credit to the original author(s) and the source, provide a link to the Creative Commons license, and indicate if changes were made. The images or other third party material in this article are included in the article's Creative Commons license, unless indicated otherwise in a credit line to the material. If material is not included in the article's Creative Commons license and your intended use is not permitted by statutory regulation or exceeds the permitted use, you will need to obtain permission directly from the copyright holder. To view a copy of this license, visit http://creativecommons.org/licenses/by/4.0/.
\end{abstract}

(c) The Author(s) 2019

\footnotetext{
${ }^{1}$ Board of Governors-Regenerative Medicine Institute, Cedars-Sinai Medical Center, Los Angeles, CA 90048, USA. ${ }^{2}$ Department of Biomedical Sciences, Cedars-Sinai Medical Center, Los Angeles, CA 90048, USA. ${ }^{3}$ Department of Medicine, University of California, Los Angeles, CA 90048, USA. ${ }^{4}$ Metabolism and Mitochondrial Research Core, Cedars-Sinai Medical Center, Los Angeles, CA 90048, USA. ${ }^{5}$ Heart Institute, Cedars-Sinai Medical Center, Los Angeles, CA 90048, USA. ${ }^{6}$ iPSC Core, The David Janet Polak Foundation Stem Cell Core Laboratory, Cedars-Sinai Medical Center, Los Angeles, CA 90048, USA. Correspondence and requests for materials should be addressed to D.S. (email: dhruv.sareen@cshs.org)
} 